\title{
Being young female Muslims in Islamic fictions: Moral anxiety, faith primacy and ideal image discourse
}

\author{
Rani Dwi Putri ${ }^{*}$ \\ ${ }^{1}$ Department Sociology, Universitas Gadjah Mada, Indonesia \\ * Corresponding author \\ E-mail address: ranidwiputri@ugm.ac.id \\ DOI: https://doi.org/10.21107/sml.v4i1.8715
}

\begin{tabular}{|c|c|}
\hline Article Info & Abstract \\
\hline $\begin{array}{l}\text { Keywords: } \\
\text { female } \\
\text { Muslim } \\
\text { youth } \\
\text { Asma Nadia } \\
\text { Islamic fiction }\end{array}$ & $\begin{array}{l}\text { This article examinesthe representation of Indonesian young female Muslims } \\
\text { in Asma Nadia's works. While previous studies have drawn dynamic } \\
\text { transition in real life, this study provides an alternative narrative of being } \\
\text { a young female Muslim in Islamic fiction in the context of simultaneous } \\
\text { contemporary development in Indonesia with the raising of public piety. } \\
\text { This study employed textual analysis method by making categories based } \\
\text { on specific themes and understanding each conversation, storyline, and } \\
\text { setting of Nadia's three works, namely "Assalamualaikum Beijing" ("May } \\
\text { Peace Be With You, Beijing"), "Jilbab Traveller: Love Sparks in Korea," and } \\
\text { "OTW Nikah" ("On The Way to Marriage"). The author concludes that Asma } \\
\text { Nadia places moral anxiety and faith primacy as a frame young female } \\
\text { Muslims experience. Moral anxiety reflects a dilemma of the proper way } \\
\text { and advantageous outcome to achieve a successful transition. Faith primacy } \\
\text { describes a set of spirits for connecting Islamic values and virtuous roles } \\
\text { in each life stage. Furthermore, like many popular cultures containing the } \\
\text { ideology of contestation, Asma Nadia's works also provide a discourse } \\
\text { about an ideal image that potentially influences and forms the imagination } \\
\text { of readers. }\end{array}$ \\
\hline
\end{tabular}

Citation suggestion:

Putri, R. D. (2021). Being young female Muslims in Islamic fiction: Moral anxiety, faith primacy and ideal image discourse. Simulacra, 4(1), 1-13. https://doi.org/10.21107/sml.v4i1.8715 


\section{Introduction}

Several social-politic changes took place following the fall of the New Order Era in Indonesia. Some scholars (Afrianty, 2020; Bruinessen, 2013; Hasan, 2013; Hefner, 2001; Nilan \& Mansfield, 2014; Rijal, 2005; SmithHefner, 2007; Heryanto, 2011) have noted that after Suharto's downfall, Islam becomes a dominant identity in the politics and a public discourse in Indonesia. Heryanto (2011) describes how Islam is associated with 'public pleasure.' He argues that until the mid-1980s, Islam was not usually associated with wealth, modernity, urban lifestyle, or popular culture (p. 63). This condition remarkably changed where Islam becomes the forefront of the production and consumption of popular culture (Heryanto, 2014). This changes is then followed by the trend of Islamic films (Barkin, 2014; Hariyadi, 2013), the spreading of hijab (veil), and other Islamic attributes in urban life (Jones, 2007; Nilan \& Mansfield, 2014; A. Utomo et al., 2018).

The emergence of Islamic fiction is part of those phenomena. For instance, this is fiction texts written by Asma Nadia. Nadia has actively produced many books, novels, and short stories with Islamic themes, figures and values. Until today, Nadia has published about 59 works. Some of her works were critically acclaimed and are best-selling books. Furthermore, some of her works, such as "Jilbab Traveller: Love Spark in Korea," "Assalamualaikum Beijing" ("May Peace Be With You, Beijing"), "Pesantren Impian" ("Dream Islamic Boarding School"), "Rumah Tanpa Jendela" ("Home without Window"), "Surga yang Tak Dirindukan" ("Unwanted Heaven"), "Emak Ingin Naik Haji" ("Mother Wants To Go Hajj") and "Cinta LakiLaki Biasa" (Ordinary Man Love) were also adopted to box office movies. Most of her works reveal dynamic stories in households and families, women and their dreams, as well as young people with their love stories.

This article attempts to identify how Asma Nadia constructs the idea of young female Muslims throughout her works. The researcher want to uncover how a female writer builds the young female Muslims figures through Islamic fiction in the era of post-authoritarian Indonesia and whether female writers have an impact on gender relations. Udasmoro (2017) argues that the presence of female writers with their narrative about womanhood does not guarantee equality ideology. The hegemonic masculinity (Connell, 1995) and the dominant structure position women in the domestic arena (Udasmoro, 2017) has become embedded social imaginary (Taylor, 2004), even among female writers. Putri (2020) has also proven that the negotiation process is significant in several Asma Nadia's works. It is argued that, rather than portraying an 'authority' for women thoroughly, Asma Nadia prefers to negotiate by applying Islamic symbols and values amid a developed modern identity in her works. A negotiation process is remarkably important to actualize figures of female Muslims associated with modernity products (Heryanto, 2014), yet remains within the Islamic circle symbolically and morally.

Previous studies summarize an overview of how Asma Nadia develop young female Muslims characters and their transition to work (career), marriage, and education. First, the female writer has not ensured to discharge from masculinity. Then, the raising of public piety has shaped and influenced the interpretation and reflection process of being a young female. Other studies, such as Herrera \& Bayat (2010); Minza (2014); Sutopo (2014); Sutopo \& Putri (2019) have revealed dynamic transition and youth in a real-life. On the other hand, this present study wanted to uncover alternative narrative of being young female Muslims 
in Islamic fictions. Like many popular cultures in ideological contestation, Asma Nadia's works also potentially contribute to spreading ideal images of young female Muslims in the context of contemporary development Indonesia.

\section{Method}

This study employed a qualitative method by interpreting Asma Nadia's works using textual analysis. Barker (2004) argues that in the cultural studies, texts refer to broad objects, including textual words, activities, sounds, pictures, and other practices that have meaning. In this frame, Barker (2004) offers semiotics analysis to identify and explore how 'meaning' is formed through texts by applying cultural codes. It means that the analysis process focuses on the ideology of the text.

First, texts are chosen from the stories of young female Muslims and their threedomain transition. This study, therefore, focuses on three Asma Nadia's works, namely "Assalamualaikum Beijing" (2014), "Jilbab Traveller: Love Sparks in Korea" (2015), "OTW Nikah" ("On The Way To Marriage") (2019). "Assalamualaikum Beijing" is about a female journalist named Asmara. She got a job to do a cover on Beijing, which brings her into a new journey of life and love. "Jilbab Traveller: Love Sparks in Korea" is about the figure of Rania and her traveling stories. Rania represents a successful young writer who gains Residency Exchange Programs for Asian writers in Korea. During that journey, besides gaining excellent opportunities to visit popular destinations in Korea, Rania is also involved in romantic stories with a young Korean named Hyun Geun. "OTW Nikah" is a collection of short stories on various journeys to marriage, such as broken heart, taa'ruf, dating, and engagement.

The researcher then made categories based on the significant theme to obtain a pattern. Understanding the conversation among figures, storyline, and the setting is helpful to find a meaning of texts. The process of interpretation itself is subjectively developed by referring to concepts and theories from previous studies. Furthermore, some visual representations are analyzed to corroborate the finding.

\section{Results and Discussion}

This section discusses three Asma Nadia's works, namely "Assalamualaikum Beijing," "Jilbab Traveller: Love Sparks in Korea," and "OTW Nikah". In order to understand how Asma Nadia builds the idea of being a young female, the discussion was focused on three domains of youth transition. Following the argument of Wyn \& White (1997: 95), youth transition is a concept of imagery of process, fluidity, and change to a set endpoint: adulthood. In this perspective, domains such as education, work (career), and marriage are significant to define a social position in their next stage of life (Minza, 2014; Parker \& Nilan, 2013; Sutopo, 2014). Wyn \& White (1997) argue that the concept of youth transition is closely related to the horizontal perspective of social life and integrally to the vertical frame of references such as the identity of men, women, and geographical location and cultural identification.

This article will have four sections. First, it starts by identifying the contextual setting of contemporary development in Indonesia and public piety growths. This part is important in understanding how women and youth are positioned in those contexts. Second, the article discusses the education and career (work) domain in the frame of mobility. Third, the transition to marriage will be drawn through romantic-Islamic love among female figures. Fourth, the discussion about hijab is added to address how female figures are actualized through youth culture. 


\section{Women, youth and the raising of public piety}

A number of emerging public expressions of religiosity increases following Indonesia's democratic reforms in 1998. Bruinessen (2013:4), for example, reveals the trend of the conservative turn in the contemporary development of Indonesia after the regime of Suharto, followed by the MUI's (Majelis Ulama Indonesia) governmentindependence declaration with its own agenda. With its independence, MUI has asserted their positioning as "an attempt to demarcate a role more aligned with the umma" (Bruinessen, 2013: 4). Since then, MUI has played a significant role in the interface between the secular Indonesian government and the Indonesian umma, especially during a time of great change (Gillespie, 2007: 202). It indicates that the Indonesian Muslims may have preserved conservative views (Bruinessen, 2013), or the independence of MUI has brought into more conservative represented by some controversial fatwa along the post-reform (Gillespie, 2007). Furthermore, the rise of Islamist extremism (Singh, 2007), followed by inter-religious conflicts in some areas in Indonesia (McRae, 2013), enhances a variety of emerging Islamic piety in public life.

On the other side, the symbolic identities of Islam in the print media (Hefner, 2001a), new lifestyles (Nilan \& Mansfield, 2014), and popular culture (Heryanto, 2014; Nilan, 2017) are also part of the spectacular presence of Islam in public life. Hasan (2009) illustrates those phenomena through some examples. The consequence of popular piety, such as the proliferation of Islamic business institutions that have achieved prominence and become a new symbol of elitism, is noteworthy. Aside from emerging new $d a^{\prime} w a h$ (Islamic proselytize) agent with creatively translating and packaging Islamic messages for mass consumptions (Hasan, 2009), the popular piety also potentially permits a shaped new perception about what good Muslim and moral are in the public life.

Then how are those related to women? In the broader context of Muslim society, Moghadam (1993) reveals that women do not have a strategic position both legally and socially in public life. The dominant interpretation of Al-Qur'an and hadith permit to assign of women into domestic roles and live in a patriarchal belt. However, can this justify the fact that women are unbenefited in the context of raising public piety in Indonesia? In fact, following Afrianty's (2020: 76) argument, the democratic system in Indonesia allows the contestation of varying views on various aspects, which often leads to tension between different forms of authority, including religious ones. Instead of concerned with personal faith or piety, the values and practices of piety in public lives are increasingly interpreted in a patriarchal manner (Afrianty, 2020). Therefore, it can be argued that those situations have taken the status of women into a more contested position, and consequently, have positioned women into a more marginalized position in some cases.

The social position as a female and Muslim, then, would bring to different experiences of transition. Herrera \& Bayat (2010) assert that different cultures and backgrounds may generate diverse experiences of being young. The context of where they grew up followed by the inherent identity such as family, class, and gender (Furlong \& Cartmel, 2007) can influence and shape how young people experience and interpret youth, including their trajectories in life. Herrera \& Bayat (2010:6) add that such a woman is a socially constructed category that carries certain time and culture-bound where it means that even in the same layer, every woman would potentially experience and express differently. 


\section{Mobility: Achieving career and taking da'wah}

Economic developments and socialpolitical changes in Indonesia have stimulated broader education access (Nilan, 2008; Putri et al., 2020) and work opportunity (Tsutsui, 2013), particularly for women. These also underlie most settings of Asma Nadia's works, including the three objects in this study. In "Jilbab Traveller: Love Sparks in Korea," Asma Nadia develops Rania character as a young female Muslim with a high educational background. Although was diagnosed with multiple diseases and has unfortunate economic condition at the early stage of her adolescence, Rania can rise from hopelessness and shine in the next phases of her life.

Like Rania, Asmara, the main character of the "Assalamualaikum, Beijing", is also delineated as a well-educated young female Muslim with a successful journalistic career. "OTW Nikah," though come in multiple short stories format, Asma Nadia tends to encode most of the figures as an 'ideal woman' with high education, excellent achievement, and a stable economy. For example, in one of the short stories titled "OTW Nikah", Putri, the main character, is represented as a young female having higher achievement than other women.

Cuma Putri satu-satunya mahasiswa yang proposalnya diterima untuk dipresentasikan di universitas di Leiden. Pembicara lain semua sudah memiliki sederet title setelah nama mereka. (Nadia, 2019: 227). (Putri is the only one student whose proposal is accepted to be presented in a university in Leiden. Other speakers have had many degrees)

Having a fabulous qualification background, of course, Asma Nadia envisages all of the figures beyond the domestic imaginaries. Rania, for instance, is encoded in a frame of remarkable mobility with a vigorous tagline "berjilbab nggak berarti kamu nggak bisa keliling dunia!" ("using hijab does not mean you cannot travel around the world") (Nadia, 2015). It reflects how Asma Nadia disguises the boundaries of Islamic construction about women and publicity. However, rather than loathing those structures, Asma Nadia negotiates it by juxtaposing "an ideal modern young woman" and "Islamic symbol and value."

Mobility is a part of how young people navigate themselves toward their aspirations (Marzi, 2017). In other words, mobility constitutes a form of modern life demands and indicates an endeavour in diminishing risks of future uncertainty of the late modernity era (Beck, 1992). While the pressure of ideality in modern life is likely to tantalise, religious values are simultaneously needed to nurture the faith and ensure still being part of the devout Muslim community. To negotiate both, Asma Nadia reconstructs and reinterprets the meaning of mobility becoming a more religious journey, rather than 'a secular' one (Putri, 2020).

"Setiap tempat yang didatangi selalu memberi pelajaran baru. Sekaligus membakar hasrat untuk semakin mendalami Islam agar mampu memberikan penjelasan yang lebih baik. Bagaimanapun dengan jilbabnya, Rania seakan dituntut untuk memenuhi harapan sebagai 'Wikipedia' Islam sederhana. Terlebih saat berada di negeri-negeri minoritas Islam." (Nadia, 2015: 12) (Every place we go always give a new lesson. It arouses our desire to know more about Islam. Because she wears hijab, Rania is likely asked to be a simple "Wikipedia" for Islam, especially when she is in Islamic minority countries.)

"...juga misi mendunia dan menebar rahmat, selain mengoreksi citra muslim-muslimah." (Nadia, 2015: 126) (... also the mission to travel the world, spread the Islamic Grace, and rectify the images of female and male Muslim) 
The texts above illustrate that mobility covers a set of missions to spread Islamic values and rectify any negative images. By positioning Rania as "Wikipedia of Islam" seems that she is required to understand firmly about Islam. Instead of imagining mundane mobility, she should deal with a virtuous demand. It takes to ensure that the figure keeps on her faith, aside from enjoying her shine opportunities.

\section{Romantic (Islamic) love}

Some scholars (Bannett, 2005; Jones et al., 2015; Nilan, 2008; Smith-hefner, 2005; Tsutsui, 2013; Utomo, 2014) have drawn a change in marriage transition among youths in Indonesia. For example, Utomo et al. (2018) point out a transition to self-choice marriage among young people, in which it has shifted the tradition of arranged marriage. By focusing on 1552 respondents domiciled in Jakarta, Utomo et al. (2018) conclude that only around 4 per cent of young people experience an arranged marriage. Another study, Smith-Hefner (2005), conceptualizes what she called a "new Muslim romance" positioning young Muslims in the cultural and social changes. She argues that new opportunities and autonomy for Muslim women as yet trapped in moral ambivalence. They want to take advantage of the new freedoms and options but feel uncomfortable with new possibilities for unsupervised interactions with members of the opposite sex (Smith-Hefner, 2005: 453).

We know that Islam through Al-Quran and Hadiths has clear moral guidelines arranging an appropriate relationship of premarital between men dan female Muslims, and it provides rules for courtship and marriage (Smith-Hefner, 2005). Thus, Asma Nadia prefers to locate ta'aruf as an appropriate way to finding "jodoh" (a soulmate arranged by God) and modest love as a set of romantic stories among young female figures of her works. While youth cultures of premarital relationship in Indonesia (L. R. Bennett, 2005; Nilan, 2008) show some variety such as "pacaran bekstrit" (backstreet courtship), which potentially offers greater freedom to express physical affection as well as sexual contact and "pacaran modern" by spending time in public leisure activities.

In three of her works, Asma Nadia builds the opposite understanding and outcome of dating and ta'aruf. In the short story of "Kilau Untuk Kiara" (Sparkle for Kiara) in "OTW Nikah" for example, on the one hand, she presents a storyline about Kiara that experiences many dating before marriage but always broke up in the end - which is seemingly showing an unavailing side.

\begin{abstract}
"Aku enggak pernah pacaran karena enggak tahu pasti untuk apa pacaran." (I have never been dated, I do not know what people do when dating)

"Kok gitu, Mba? Pacaran, kan, biar saling kenal. Syukur-syukur bisa lanjut ke jenjang pernikahan!" sela Kiara (Why is that, Sis? Dating, is, to know each other. It is better if you can continue to marriage)

"Masalahnya aku enggak yakin kita harus pacaran seperti itu untuk saling kenal. Kalau untuk menikah banyak teman mba Ira yang menikah tanpa proses pacaran." (The problem is, that I am not sure we should date to know each other. If the purpose is marriage, many of $\mathrm{Mba}$ Ira's friends marry without dating)
\end{abstract}

(Nadia, 2019: 2 Kilau Untuk Kiara in OTW Nikah)

On the other hand, represented in the texts above, Asma Nadia ends her storyline with the dialogue that changes Kiara's mind to leave her dating and try to, succeed in the end, find her soulmate through ta'aruf. This change is also accompanied by her vailed appearance and joining a religious 
community on campus. Asyari \& Abid's (2016) argue that ta'aruf campaign is part of expanding Tarbiyah Movement targeting many campuses as propaganda strategy. The campaign aims to achieve the Tarbiyah Movement's goals by instilling Islamic values to family, then Islamizing society and the state in the end. Smith-Hefner (2019) adds that Muslim student organizations, aside from conducting the role of dakwah by promoting Islamic values in the campus areas, provide a chance to find a potential mate among members.

Furthermore, in other short stories, she also emphasizes that ta'aruf also offers such opportunities for both sexes to recognize "exactly" each other, and they can decide yes or no in the midst or end of these moments. Unlike dating, however, every moment of the meeting is, of course, always accompanied by two or more family members.

Memang enggak ada pacaran dalam Islam, tapi ta'aruf kan ada. Kita boleh saling mengenal, boleh nanya yang banyak di sana. Selama ta'aruf, kita mencoba mengenal betul karakter calon suami. Supaya bisa menjawab ya atau tidak. (Nadia, 2019: 163-164) (Indeed, there is no dating in Islam, but it provides ta'aruf. We can know each other, give many questions in there. During the ta'aruf, we try to know exactly the character of husband candidates, in order to answer Yes or No)

Understandably, ta'aruf seems as an appropriate way to guard and protect particularly young women by avoiding any possibility of physical touching and sexual contact. Smith-Hefner (2005) argues that it is partly an attempt at how young women uphold the family name by assuring their virginity before the marriage. On the other side, it also brings more certainty to screen the candidates having a religious credential.
"Iya." Lanjutnya. "yang penting Ikhwan. Alim, saleh, sudah mampu mencukupi keluarga. Selesai." "kalau bisa mapannya kayak Abu Bakar Shidiq!" (Nadia, 2019:155) (Yes. She continued. The important thing he is Ikhwan. Pious, devout, have done been able to fulfil family need. Finish. If can the established economy is like Abu Bakar Shidiq)

“... dia tak yakin sanggup membayangkan pernikahan dengan pasangan berbeda budaya dan agama". (Nadia, 2014: 11) (... She not sure be able to imagine married to different culture and religion)

"Dan dia harus seorang muslim yang baik."

Syarat mutlak. Tidak peduli betapa tampan atau mapannya seseorang. Tidak soal seberapa sering kecerdasan atau kelucuannya membuat Rania terpesona. Dia tidak mungkin menikah dengan lelaki yang berbeda agama. (Nadia, 2015: 210) (And he must be a good Muslim. An inescapable requirement. No matter how handsome and established he is. It is not about how much often his intelligence and humour make Rania bewitched. She is impossible marrying to a man with different religion)

The texts above try to draw an ideal man. Besides devout and good male Muslims become the main requirement, she places having the same religion as the undebatable and inescapable precondition. Furthermore, even though located in additional criteria, having economic stability and physical appearance is presumably an enticing offer. These are reflected in both novels "Assalamualaikum Beijing" and "Jilbab Traveler: Love Sparks in Korea", in which Asmara and Rania are surrounded by not only good-look men but also having potential future economic security. Rania, for instance, is adored by a Korean man named Hyun Geun. The guy is illustrated by having high photography skills with a good-look face visualized through Morgan Oey, an Indonesian actor, in its film version. With his 'modest love', a feeling deep and heartfelt 
affection without having pleasurable sexual contact, Hyun Geun's figure succeeded to defeat his rival, a richer man, and got married to Rania at the end of the story.

In the real-life, Nilan (2008) points out that in the context of the urban middle-class devout man and having a permanent job are recognized as criteria of an ideal husband, besides having a sense of humor as a desired partner characteristic. A permanent job reflects financial security need encouraging by a period of dire economic crisis simultaneous with the growth of unfettered consumption choices (Nilan, 2008: 79) among Indonesian youth nowadays. Other studies, Yeung \& Mu (2020) argue that ethnicity/ race, origin, social-economic background, and religion still play important roles in the marital relation in the context of Asian people. Utomo (2020) highlights, however, that in the context of Indonesia, among concepts of identities, religion ranks the highest position of marital consideration. Understandably, Aini (2008) argues that, besides religious doctrines, Indonesia marriage law tends to not allowing the interreligious marriage.

\section{Hijab: Being pious and fashionable woman}

"Jangan salah. Ketika gue mutusin berjilbab, itu berarti gue memerdekakan diri gue. Dengan jilbab, gue yang sepenuhnya bebas menentukan siapa cowok yang boleh melihat gue, seberapa mereka boleh melihat gue, dan siapa yang tidak! Jilbab cuma menutupi kepala, bukan otak!" (Nadia, 2019: 245) (Make no mistake. When I decided to wear a hijab, it means that I liberate myself. With the hijab, I completely free to determine who the guys can see me, how much they can see me, and who cannot! The hijab only covers the head, not the brain!)

The texts above draw that the hijab precisely represents authority for women to choose and determine who and how they are. However, some Quranic interpretations construct that there is a vivid guideline of how a woman can show her "aurat" (parts of the body that should not be seen in the public) in which it is namely mahram. There are some arguments thereafter placing jilbab in the context of powerless and symbolically as part of gender inequality. Guindi (1999) argues that the emerging of many veil discourses unavoidably depends on applied perspectives upon its inherent social and historical contexts. For example, Guindi (1999:3) mentions Western-ideology feminists who have dominated the discourse in viewing the veil as an aspect of patriarchies and a sign of women's backwardness, subordination, and oppression. Mernissi (1991) asserts that historically, the hijab closely related to a pressing crisis at the end of the twentieth-century placed women's bodies as a symbolic representation of a community. It represents a juxtaposition: a resource of havoc and a social structure guard in another side (Rohmaniyah, 2019), and afterward render hijab into the contested discourse.

Asma Nadia's attempt to rectify any stigma of the hijab is understandable. Besides vigorously serving such defense by dominantly issuing an authority image rather than restraints, she also aligns the hijab with consuming practices. It seemingly allows young female Muslims to actualise herself through "mixing and matching the dresses". In "Jilbab Traveller: Love Sparks in Korea" novel, for instance, she visualizes the figure of Rania, a woman wearing a veil combined with a loose $t$-shirt, matching jacket, jeans skirt, stylist blouse, and booth (see Figure 1).

Furthermore, she also addresses one Muslim clothing brand to define the figure's characteristics as a modest and agile woman (Putri, 2020), besides presenting a fashionable impression. 

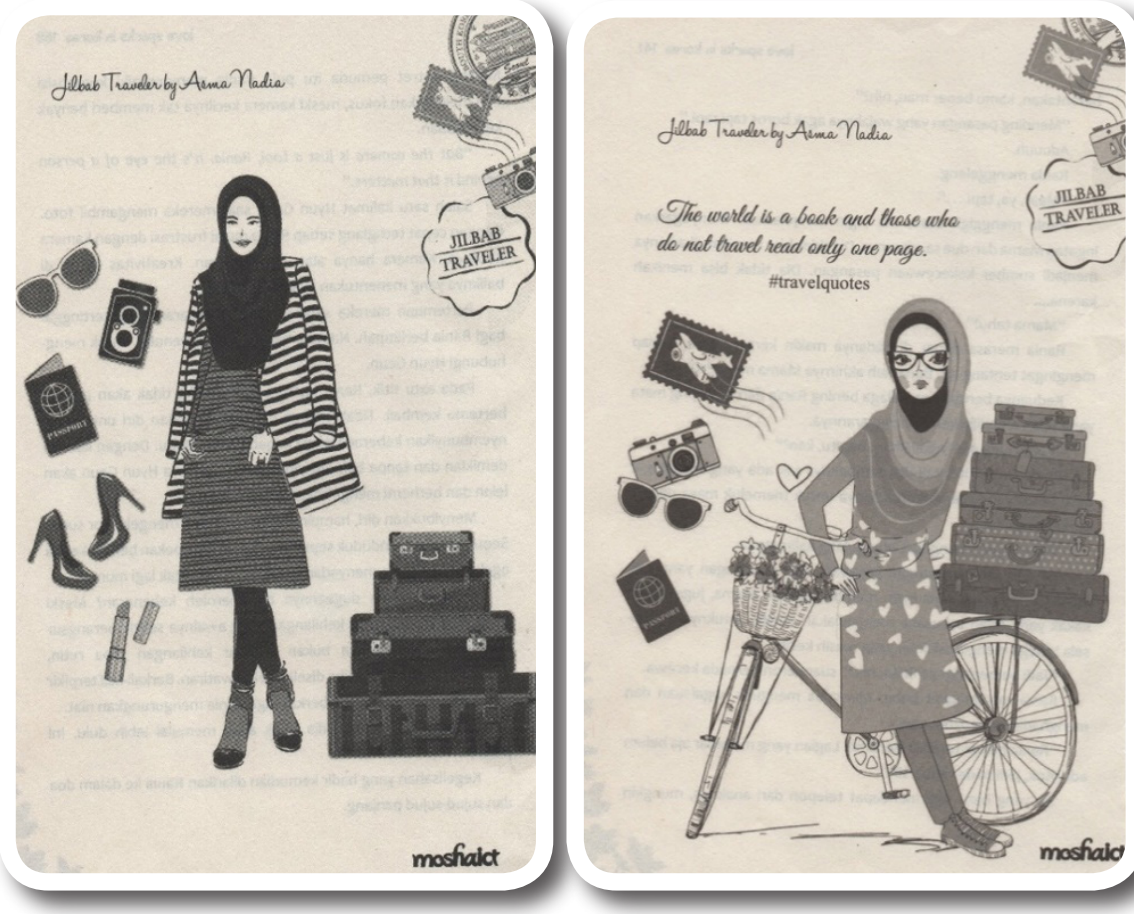

Figure 1

Visual representation of Jilbab Traveler by Asma Nadia

Source: Nadia, 2015

Beberapa baju yang selesai dipantaskan dengan wana kerudung digantungkan ke lemari. Bajubaju di dalamnya dikategorikan sesuai warna. Memudahkan ketika mencari padu padan untuk traveling. Blus katun berwarna merah misalnya, bisa dikenakan dengan rok jeans atau rok merah kotak-kotak yang ringan. (Nadia, 2015: 136) (Some dresses finished are customized by hijab's colour hung in the cupboard. The Dresses are categorized by colour. It simplifies when looking for mix and match for traveling. Red cotton blouse for example, it can be worn with a jeans skirt or a light plaid red skirt)

Confirmed by Jones (2010:622), through her analyses of some Asma Nadia's works particularly about the hijab, she concludes that Asma Nadia has generated two contrasting concerns. First, Asma Nadia attempts to correct the reputation that wearing a hijab is out of style, provincial, and tasteless by demonstrating some "tutorials" how wear Muslim dress should be to increase self-confidence and sense of beauty. Second, however, in some narratives, she mentions such a possibility, that some women wear Muslim dress for the wrong reasons: just being to be trendy. The emphasis of "pious and correct dressing but still stylish and trendy" is paramount to conceive how Asma Nadia constructs the idea of being a young female Muslim.

\section{Conclusion}

Asma Nadia's works are a notable example to explain the emerging public expression of religiosity phenomena in Indonesia. Apart from the flowering Islamic literary, her works also potentially generate an alternative narrative of the ideal young femaleMuslim in the context of contemporary development Indonesia simultaneously with the spectacular presence of Islam in public life. Despite bringing more opportunities to 
access economy and education for women, Indonesia's development after Suharto is still, unfortunately, translated in patriarchal perspectives. Consequently, growing as a young female Muslim is frightened by the dynamic transition and contested morality in public life.

While previous studies of youth transition in real life have shown vulnerable trajectories, unexpected outcomes, and dynamic experiences, this study finds an attempt to draw how being an ideal young female Muslim in the context of contemporary development simultaneously with the raising of public piety. The term ideal reflects the representation of a more stable life and shines outcome. Rather than showing labor market entry, family change and generation relationship, school failure, and economic insecurity that are frequently highlighted in the problems of young people, Asma Nadia prefers to place all figures upon moral anxieties and faith primacy as a frame of how they experience 'being young female'. In the transition to education and work, Asma Nadia built the figure as a young female Muslim with tertiary education and a successful career where mobility is required to achieve them.

However, playing roles as a preacher that spread grace and rectify female and male Muslims' images should be taken to ensure her piety and faith, besides enjoying her shine opportunities. In the transition to marriage, ta'aruf seems an appropriate way to guard and protect young women by avoiding any possibility of physical touching and sexual contact. This, aside from assuring the chastity and dignity before marriage, also offers more possibility to obtain the candidates having a religious credential. Another paramount issue for understanding the idea of being a young female Muslim, Asma Nadia places a pious-stylish dress to actualize self-authority, besides fulfilling the faith. Consuming practices, however, should be held to express the self-authority through "mixing and matching".

Like other kinds of popular culture, Islamic fiction also potentially contains an ideology contestation as well as provides a set of discourse and counter-discourse ( $\mathrm{T}$. Bennett \& Woollacott, 1987). Indeed, the experiences of being a young female Muslim in Asma Nadia's work have not thoroughly portrayed the complexity of real realities. However, it offers an alternative idea of how being an ideal young female Muslim that potentially influences and forms the readers envisaging their future life. This includes how they actualize their identity in public life, situate social position upon hegemonic masculinity, and negotiate the faith amid modernity demands.

\section{Declaration of Ownership}

This article is my original work.

\section{Conflict of Interest}

There is no conflict of interest to declare in this article.

\section{Ethical Clearance}

This study was approved by the institution.

\section{References}

Afrianty, D. (2020). Rising public piety and the status of women in Indonesia two decades after Reformasi. TRaNS: TransRegional and-National Studies of Southeast Asia, 8(1), 65-80. https://doi.org/10.1017/ trn.2019.14

Aini, N. (2008). Inter-religious marriage from socio-historical Islamic perspectives. Brigham Young University Law Review, 669-705. https://digitalcommons.law. byu.edu/lawreview/vol2008/iss3/1 
Asyari, S., \&Abid, M.H.(2016). Expanding the Indonesian tarbiyah movement through ta'āruf and marriage. Al-Jami'ah: Journal of Islamic Studies, 54(2), 337-368. https:// doi.org/10.14421/ajis.2016.542.337-368

Bannett, L. R. (2005). Women, Islam and modernity single women, sexuality and reproductive health in contemporary Indonesia. Routledge.

Barker, C. (2004). Cultural studies. Kreasi Wacana.

Barkin, G. (2014). Commercial Islam in Indonesia: How television producers mediate religiosity among national audiences. International Journal of Asian Studies, 11(1), 1-24. https://doi. org/10.1017/S1479591413000181

Beck, U. (1992). Risk society: Towards a new modernity. Sage.

Bennett, T., \& Woollacott, J. (1987). Bond and beyond: The political career of a popular hero. Macmillan Education.

Bruinessen, M. V. (2013). Contemporary developments in Indonesian Islam: Explaining the conservative turn (New ed.). Institute of Southeast Asian Studies.

Connell, R. W. (1995). Masculinities (First Edition). University of California Press.

Furlong, A., \& Cartmel, F. (2007). Young people and social change: New perspectives. McGraw-Hill/Open University Press.

Gillespie, P. (2007). Current issues in Indonesian Islam: Analysing the 2005 council of Indonesian ulama fatwa No. 7 opposing pluralism, liberalism and secularism. Journal of Islamic Studies, 18(2), 202-240. http://www.jstor.org/ stable/26199807

Guindi, F. E. (1999). Veil: Modesty, privacy and resistance. Berg.

Hariyadi, H. (2013). Finding Islam in cinema: Islamic films and the identity of Indonesian Muslim youths. AlJami'ah: Journal of Islamic Studies, 51(2),
443-473. ajis.2013.512.443-473

https://doi.org/10.14421/

Hasan, N. (2009). The making of public Islam: Piety, agency, and commodification on the landscape of the Indonesian public sphere. Contemporary Islam, 3(3), 229250. https://doi.org/10.1007/s11562-0090096-9

Hasan, N. (2013). The making of public Islam: Piety, democracy and youth in Indonesian politics. Sukapress.

Hefner, R. W. (2001a). Print Islam: Mass media and ideological rivalries among Indonesian Muslims. Indonesia, 64, 77103. https://doi.org/10.2307/3351436

Hefner, R. W. (2001b). Public Islam and the problem of democratization. Sociology of Religion, 62(4), 491-514. https://doi. org/10.2307/3712438

Herrera, L., \& Bayat, A. (2010). Being young and Muslim: New cultural politics in the global south and north (1st ed.). Oxford University Press.

Heryanto, A. (2011). Upgraded piety and pleasure: The new middle class and Islam in Indonesian popular culture. In A. Weintraub (Ed.), Islam and popular culture in Indonesia and Malaysia. Routledge.

Heryanto, A. (2014). Identity and pleasure: The politics of Indonesian screen culture. NUS Press.

Jones, C. (2007). Fashion and faith in urban Indonesia. Fashion Theory, 11(2-3), 211-231. https://doi. org/10.2752/136270407X202763

Jones, C. (2010). Materializing piety: Gendered anxieties about faithful consumption in contemporary urban Indonesia. American Ethnologist, 37(4), 617-637. https://www.jstor.org/ stable/40890778

Jones, G. W., Hull, T. H., \& Mohamad, M. (2015). Changing marriage patterns in Southeast Asia: Economic and socio-cultural dimensions. Routledge. 
Marzi, S. (2017). Aspirations and social mobility: The role of social and spatial (im)mobilities in the development and achievement of young people's aspirations. In C. N. Laoire, A. White, \& T. Skelton (Eds.), Movement, mobilities, and journeys. Springer Singapore.

McRae, D. (2013). A few poorly organized men interreligious violence in Poso, Indonesia. Brill.

Mernissi, F. (1991). Veil and the male elite: A feminist interpretation of women's rights in Islam. Perseus Books Publishing.

Minza, W. M. (2014). Growing up and being young in an Indonesian provincial town. University of Amsterdam Press.

Moghadam, V. M. (1993). Modernizing women: Gender and social change in the Middle East (women and change in the developing world). L. Rienner Publishers.

Nilan, P. (2008). Youth transitions to urban, middle-class marriage in Indonesia: Faith, family and finances. Journal of Youth Studies, 11(1), 65-82. https://doi. org/10.1080/13676260701690402

Nilan, P. (2017). Muslim youth in the diaspora: Challenging extremism through popular culture. Routledge.

Nilan, P., \& Mansfield, M. (2014). Youth culture and Islam in Indonesia. Wacana, 15(1), 1-18.

Parker, L., \& Nilan, P. (2013). Adolescents in contemporary Indonesia. Routledge.

Putri, R. D., Fahadi, R., Kusumaningtyas, A., Utomo, A., \& Sutopo, O. (2020). Navigating the future husband: Perempuan muda, negosiasi pernikahan dan perubahan sosial. Jurnal Studi Pemuda, 9(2), 90-103. https://doi. org/10.22146/studipemudaugm.57996

Putri, R. D. (2020). Representasi identitas Muslimah modern "jilbab traveler" dalam novel karya Asma Nadia. Jurnal Sosiologi Walisongo, 4(2), 117-132. https:// doi.org/10.21580/jsw.2020.4.2.5878
Rijal, S. (2005). Media and Islamism in postnew order Indonesia: The case of sabili. Studia Islamika, 12(3), 421-474. https:// doi.org/10.15408/sdi.v12i3.582

Rohmaniyah, I. (2019). Gender dan seksualitas perempuan dalam pertarungan wacana tafsir. Lampu Merapi.

Singh, B. (2007). The Talibanization of Southeast Asia: Losing the war on terror to Islamist extremists. Greenwood Publishing Group.

Smith-Hefner, N. (2005). The new Muslim romance: Changing patterns of courtship and marriage among educated Javanese youth. Journal of Southeast Asian Studies, 36(3), 441-459. https://www.jstor.org/ stable/20072670

Smith-Hefner, N. (2007). Javanese women and the veil in post-Soeharto Indonesia. The Journal of Asian Studies, 66(2), 389-420. https://www.jstor.org/stable/20203163

Smith-Hefner, N. J. (2019). Islamizing intimacies: Youth, sexuality and gender contemporary Indonesia. University of Hawaii.

Sutopo, O. R. (2014). Social generation, class and experiences of youth transition in Indonesia. Asian Journal of Social Sciences $\mathcal{E}$ Humanities, 3(3), 126-134.

Sutopo, O. R., \& Putri, R. D. (2019). Mobilitas, negosiasi dan transisi perempuan muda di Jawa Tengah. Jurnal Studi Pemuda, 8(1), 1-14. https://doi.org/10.22146/ studipemudaugm.45962

Taylor, C. (2004). Modern social imaginaries. Duke University Press.

Tsutsui, J. (2013). The transitional phase of mate selection in East Asian countries. International Sociology, 28(3), 257-276. https://doi. org/10.1177/0268580913484775

Udasmoro, W. (2017). Reproduksi womanhood dalam novel bunda: Kisah cinta 2 kodi karya Asma Nadia. Adabiyyāt: 
Jurnal Bahasa dan Sastra, 1(2), 182-200. https://doi.org/10.14421/ajbs.2017.01203

Utomo, A. J. (2014). Marrying up? Trends in age and education gaps among married couples in Indonesia. Journal of Family Issues, 35(12), 1683-1706. https://doi. org/10.1177/0192513X14538023

Utomo, A. J. (2020). Love in the melting pot: Ethnic intermarriage in Jakarta. Journal of Ethnic and Migration Studies, 46(14), 2896-2913. https://doi.org/10.1080/13691 83X.2019.1585008
Utomo, A., Reimondos, A., McDonald, P., Utomo, I., \& Hull, T. (2018). Who wears the hijab? Predictors of veiling in greater Jakarta. Review of Religious Research, 60(4), 477-501. https://doi.org/10.1007/s13644018-0345-6

Wyn, J., \& White, R. (1997). Rethinking youth. Allen \& Unwin Pty Ltd.

Yeung, W.-J. J., \& Mu, Z. (2020). Migration and marriage in Asian contexts. Journal of Ethnic and Migration Studies, 46(14), 2863-2879. https://doi.org/10.1080/13691 83X.2019.1585005 
